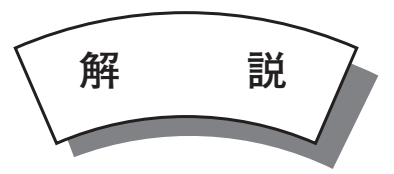

\title{
ステンレス鋼表面からのタンパク質污れの洗浄除去特性
}

\section{The Mode of the Removal of Protein from Stainless Steel Surface by Cleaning Operation}

\author{
福㟝 智司* \\ Satoshi FUKUZAKI
}

Key Words: Cleanability of stainless steel, Surface charge density, Electrostatic interaction, Affinity for protein adsorption, Biofilm formation

\section{1.はじめに}

ステンレス鋼は、食品や医薬品、生化学品分野において、 機械装置、タンク類、配管系、バルブ等の基材として広く 用いられている。これは、ステンレス鋼がさびにくい鋼で あることをはじめとして、加工性、強度、溶接性、経済性、 無毒性等の点で他の材料にはない優れた特性を有している ことにある。一方、同一の鋼種でありながら、また一定の 平滑性を付与された表面であっても、使用環境や切削加工、 表面仕上げ、前処理、溶接等の条件の違いによりステンレ ス鋼の最表面 (不動態皮膜) の界面化学的特性は大きく変 化する。その結果として、ステンレス鋼の污染性や洗浄性 の低下を招く場合がある ${ }^{1), 2)}$

タンパク質のステンレス鋼への吸着は、污れの吸着や洗 浄と深く結びついた重要な現象である。タンパク質などの 有機物の付着層は、細菌の栄養素となるばかりでなく、バ イオフィルム形成の下地になる。水溶液中においてタンパ ク質がステンレス鋼表面に吸着する過程では、種々の分子 間相互作用が働くことになる。特に、ステンレス鋼 -タン パク質間に働く静電的相互作用は、タンパク質污れの吸着 親和性や洗浄除去特性を支配する作用力である ${ }^{3)}$ 。この静 電的相互作用を理解することは、タンパク質の付着の抑制 や最適な洗浄力要素の選択において基礎的かつ重要な情報 を与えてくれる。金属材料の視点から言えば、ステンレス 鋼最表面の極性の発現と静電的特性を理解しておくことが 重要となる。

本稿では、オーステナイト系ステンレス鋼の微粒子を用 いたモデル実験系で得られた筆者らの研究成果を中心に、 洗浄効率に影響を及ぼす諸因子として、1) ステンレス鋼— 水界面の特性、2) タンパク質の吸着相互作用、3) アルカリ （水酸化物イオン）の洗浄作用メカニズム、4) ステンレス 鋼の熱履歴と洗浄性の関係について解説する。

\section{2. ステンレス鋼一水界面の特性}

ステンレス鋼の表面特性や耐食性は、表面に形成する酸 化皮膜の物理的・化学的特性に依存する。酸化皮膜は、 $\mathrm{Cr}$ や Feの酸化物や（オキシ）水酸化物からなる非晶質構造 であり、さらにその最表面には水の解離吸着によって形成 した水酸基が存在しており、固相の一部を形成している ${ }^{4)}$ 。 ここで、酸化物の格子の最前列に $\mathrm{O}^{2-}$ が位置し、金属イオ ン $(\mathrm{M})$ はその内側に位置する結晶表面の構造（二次元）を 考える（Fig. 1)。表面は化学的に不均一であり、表面の酸 素位置と金属位置によって形成される水酸基の解離特性も 異なる。すなわち、水から解離した水酸基が 1 個の金属イ オンに配位して形成された水酸基(1) 金属イオンからの 分極が弱いため水素を強く結合し、塩基性を示すようにな る(1 式)。一方、水から解離した $\mathrm{H}^{+}$と格子の酸素から形 成され、2 個の金属イオンに配位した水酸基(2)は、金属イ オンの強い分極の影響で水素の結合力が弱く、酸性の性質 を示す (2 式)。

$$
\begin{aligned}
& -\mathrm{MOH}^{0}+\mathrm{H}^{+} \rightleftharpoons-\mathrm{MOH}_{2}^{+} \\
& -\mathrm{M}_{2} \mathrm{OH}^{0} \rightleftharpoons-\mathrm{M}_{2} \mathrm{O}^{-}+\mathrm{H}^{+}
\end{aligned}
$$

このように、ステンレス鋼の表面水酸基が水溶液中で水 素イオン $\left(\mathrm{H}^{+}\right)$を吸・脱着することにより電荷を生じる。 電位決定イオンは水素イオン $\mathrm{H}^{+}$と水酸化物イオン $\left(\mathrm{OH}^{-}\right)$

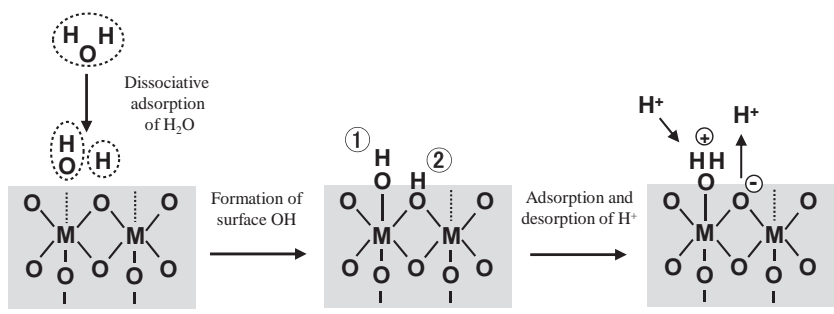

Fig. 1 A schematic representation of surface ionization of oxide layer

* 岡山県工業技術センター（ $\bar{T}$ 701-1296 岡山市北区芳賀 5301）

Industrial Technology Center of Okayama Prefecture (5301 Haga, Kita-ku, Okayama 701-1296, Japan) 

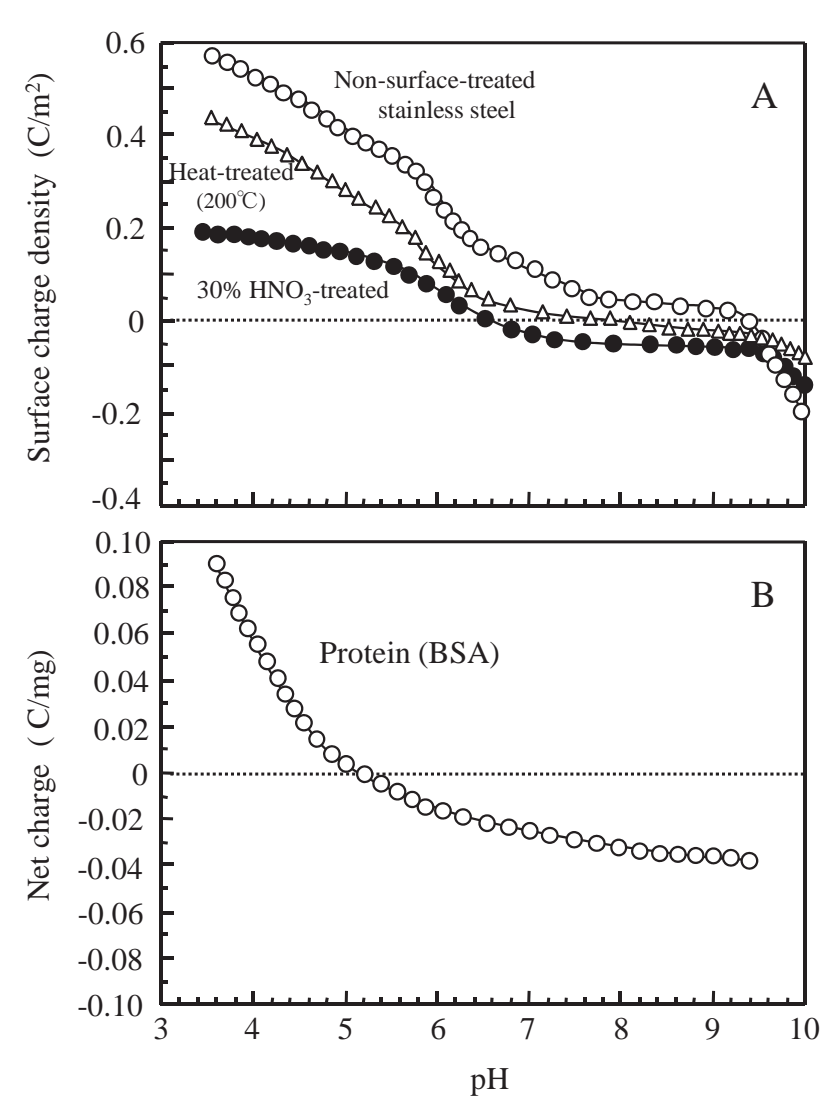

Fig. 2 Apparent surface charge densities of stainless steel particles (SUS $316 \mathrm{~L}$ ) and net charge of protein (BSA) as a function of $\mathrm{pH}$.

なので、電位差 $(\mathrm{pH})$ 滴定法を用いてステンレス鋼 - 水相 における $\mathrm{H}^{+}$と $\mathrm{OH}^{-}$の表面濃度差 $\left(\mathrm{H}^{+}\right.$の相対吸着量 $)$を定 量することにより表面電荷密度を測定することができる。 Fig. 2A にステンレス鋼（SUS 316L の微粒子試料で測定） の見掛けの表面電荷密度曲線を示す5)。正·負の電荷密度は、 $\mathrm{pH}$ に依存して変化する。また、加熱処理や硝酸処理など の前処理により、ステンレス鋼の表面電荷特性は大きく変 化することがわかる。ステンレス鋼の表面電荷特性や親水 性度は、表面水酸基の性質や水酸基化度に支配されており、 有機物污れとの吸着相互作用と密接に関係している。ステ ンレス鋼の酸化皮膜は化学的・物理的に安定であるが、そ の最表面は極性であり、極性物質の吸着や脱着が起こる動 的な反応場でもある。

\section{3. タンパク質の吸着相互作用}

食品製造機器（機械、装置、器具等）の洗浄では、ステ ンレス鋼などの硬質表面に付着したタンパク質の洗浄除去 が基本的な問題となっている。タンパク質は分子内にカル ボキシル基 $\left(-\mathrm{COOH} \rightleftharpoons-\mathrm{COO}^{-}+\mathrm{H}^{+}\right)$やアミノ基 ( $\left.\mathrm{NH}_{2}+\mathrm{H}^{+} \rightleftharpoons-\mathrm{NH}_{3}^{+}\right)$等を有する両性電解質である。夕ン

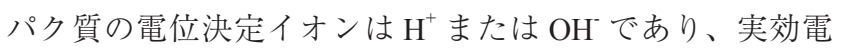
荷は水溶液の $\mathrm{pH}$ に依存して変化する（Fig. 2B）。

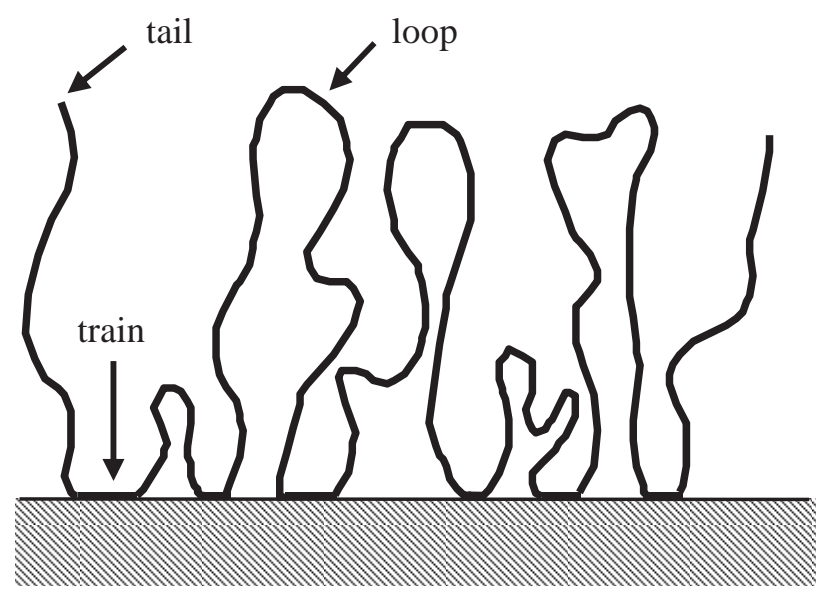

Fig. 3 A schematic drawing of three-layer model of a randomly coiled proteins adsorbed on solid surfac

タンパク質がステンレス鋼－水界面に拡散移動し、互い の電気二重層が重なり合う領域まで接近すると、種々の分 子間相互作用が働く。この近接した領域内で働く相互作用 として、遠距離 $(5 \sim 50 \mathrm{~nm})$ では van der Waals 力、静電 的相互作用、疎水性相互作用がある。二つの表面電荷の符 号が異なるときは、強い引力が働き、同符号の場合は斥力 が働く。“柔らかい”構造のタンパク質は、基質との静電 的斥力にかかわらず基質表面に吸着することが知られてい る ${ }^{6}$ 。また、近距離 $(<5 \mathrm{~nm})$ で働く主な作用力には、双 極子 - 双極子相互作用、イオン結合、水素結合、共有（配 位）結合がある。タンパク質ーステンレス鋼に働く相互作 用力は、上記の分子間力の総和で与えられるが、いずれが 支配的となるかは、ステンレス鋼の不動態皮膜の化学組成 や表面電荷密度によって大きく変化する。一般に、ステン レス鋼や酸化物に対するタンパク質の吸着の場合、分子鎖 の酸性アミノ酸残基（カルボキシル基等）が吸着に関与す ることが報告されており、複数のセグメントによる多点で の水素結合や静電的相互作用 (イオン結合)、共有 (配位) 結合が不可逆吸着に寄与すると考えられている ${ }^{7-10)}$ 。

タンパク質などの高分子物質が吸着する場合、分子鎖の どこか一つのセグメントの吸着が分子全体の吸着を意味す るので、多用な吸着形態をとることができる。一般に、夕 ンパク質のような高分子物質でさえも、固体表面に対して は複数のセグメントを介して点接触で吸着し（train）、残り の分子鎖を溶液側に伸長する形態（loop and tail）をとると 考えられている $(F i g .3)^{11)}$ 。また、タンパク質の吸着の場合、 油膜 (疎水性) のように一面に拡張して付着する場合と異 なり、吸着や洗浄における単位面積あたりの界面張力（界 面自由エネルギー）の増減がそれほど重要な因子とならな い。そのため、タンパク質が親水性のステンレス鋼表面か ら脱着する洗浄過程は、静電的相互作用による斥力（ポテ ンシャルエネルギーの増加）に基づいて説明できる ${ }^{12)}$ 。 


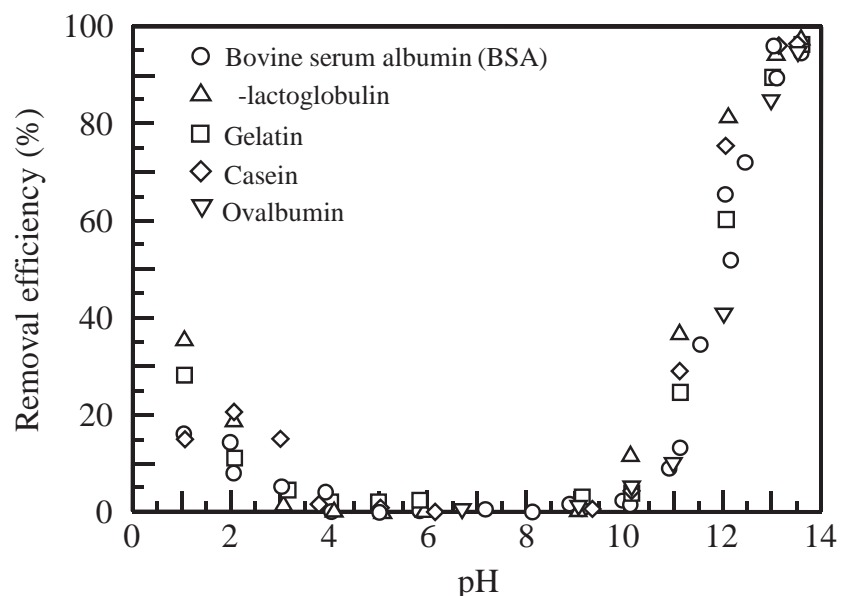

Fig. 4 Effect of the $\mathrm{pH}$ of cleaning solution on the removal of proteins from stainless steel surfaces (SUS 304).

\section{4. アルカリの洗浄作用メカニズム}

水酸化物イオン $\left(\mathrm{OH}^{-}\right)$は、タンパク質、多糖類、油脂 類等の広範囲の有機性污れに対して優れた溶解力を示すこ と、さらに付着物質ならびにステンレス鋼表面に大きな負 電荷を帯電させ吸着親和性を減少させることから、ステン レス鋼の洗浄では重要な洗浄力である。

\section{1 平衡論}

Fig. 4 に、水洗浄後にステンレス鋼（SUS 304）表面に残 存した種々のタンパク質を対象に一定時間洗浄を行ったと きの、洗浄液の $\mathrm{pH}$ と除去率の関係を示す ${ }^{13)}$ 。タンパク質 の除去率は、いずれのタンパク質においても、アルカリ性 の $\mathrm{pH}$ 領域、特に $\mathrm{pH} 11.0 \sim \mathrm{pH} 13.5$ の範囲において $\mathrm{pH}$ の 増加（ $\mathrm{OH}^{-}$濃度の増加）とともに著しく向上する。一方、 弱酸性〜弱アルカリ性の範囲では、不可逆吸着したタンパ ク質はほとんど離脱しない。強酸性溶液では $\mathrm{pH}$ の減少と ともに除去率はわずかに増加する傾向を示すが（離脱分子 はステンレス鋼の溶解に起因する)、 $\mathrm{OH}^{-}$の効果と比較する と洗浄効率は低い。また、強酸性溶液 (pH 1) での洗浄では、 タンパク質の変性・凝集が起こり除去しにくい状態に変化 する場合がある。

\section{2 速度論}

Fig. 5 に、タンパク質（牛血清アルブミン：BSA）が吸 着したステンレス鋼（SUS 316L）を種々の濃度の水酸化ナ トリウム溶液で洗浄 $\left(40^{\circ} \mathrm{C}\right)$ したときの洗浄（離脱）曲線 を示す ${ }^{13)}$ 。グラフは、洗浄時間に対して残存 BSA 量（ の自然対数值（ln $\Gamma ）$ をプロットしたものである。 $\mathrm{OH}^{-}$濃 度が 0.01M（pH 12）から 0.3M（pH 13.5）に増加するとと もに、離脱速度ならびに洗浄効率は著しく増加しているこ とがわかる。筆者らは、洗浄速度を定量的に評価するため に、吸着タンパク質分子の離脱が速度論的に 2 種類の機構

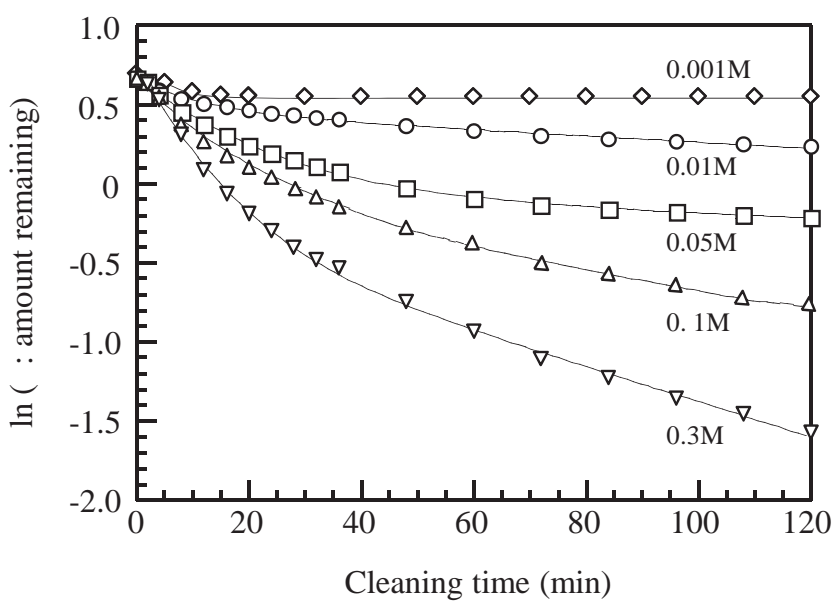

Fig. 5 Effect of $\mathrm{NaOH}$ concentration on the rate of desorption of protein (BSA) from stainless steel surfaces (SUS 316L).

（速い離脱と遅い離脱）で起こっていると仮定し、以下の離 脱モデル式を誘導して解析に用いている ${ }^{10)}$ :

$\ln \Gamma=\ln \left\{\exp \left(\ln \Gamma_{0}{ }^{\mathrm{f}}-k^{\mathrm{f}} t\right)+\exp \left(\ln \Gamma_{0}^{\mathrm{s}}-k^{\mathrm{s}} t\right)\right\}$

ここで、 $t$ は洗浄時間、「は時間 $t$ でのタンパク質の残 存量、 $\Gamma_{0}$ は $t=0$ での初発タンパク質濃度、 $k$ は $\Gamma$ に関す る一次脱離速度定数、添え字 $\mathrm{f}$ s は、各々速い離脱と遅 い離脱を意味する。 $k^{\mathrm{f}}$ は洗浄初期の離脱速度を、 $k^{\mathrm{s}}$ は洗浄 後期の離脱速度を反映する。

Fig. 5 の各測定点を結ぶ実線は、(3) 式と非線形最小二乗 法を用いて解析した結果である。(3) 式を用いた解析の結 果、水酸化ナトリウム濃度が $0.01 \mathrm{M}$ から $0.3 \mathrm{M}$ に増加すると、 $k^{\mathrm{f}}$ は $0.039 \mathrm{~min}^{-1}(0.01 \mathrm{M})$ から $0.089 \mathrm{~min}^{-1}(0.3 \mathrm{M})$ ح 2.3 倍増 加し、 $k^{\mathrm{s}}$ は $0.0013 \mathrm{~min}^{-1}(0.01 \mathrm{M})$ から $0.011 \mathrm{~min}^{-1}(0.3 \mathrm{M})$ 8.5 倍増加すると概算される。

4.3 作用メカニズム

Fig. 6 に、 $\mathrm{OH}^{-}$による洗浄除去メカニズムのモデル図を 示す ${ }^{5}$ 。強アルカリ性の $\mathrm{OH}^{-}$濃度が高い条件下では、 $\mathrm{OH}^{-}$ はタンパク質に吸着 $\left(=\mathrm{H}^{+}\right.$の脱着 $)$し、タンパク質分子鎖 が負電荷を帯びることで水和、膨潤、溶解、分散が促進さ れる。さらに、 $\mathrm{OH}^{-}$は親水性のステンレス鋼表面にも吸着 し、タンパク質とステンレス鋼の表面電荷がともに大きな 負電荷を帯びるようになる。その結果、タンパク質との間 に静電的斥力が起こることにより、吸着力が消失していき、 離脱の方向に動的平衡が傾く。最終的には、タンパク質の 吸着官能基の位置に $\mathrm{OH}^{-}$が吸着し、離脱に至る。すなわち、

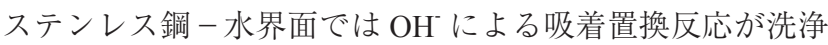
の進行に重要な役割を果たしている。

4.4 硬質表面の電荷特性と洗浄性

ここでは、表面電荷特性の異なる5つの硬質表面として

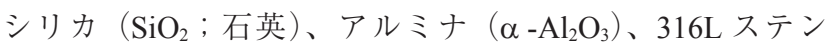


(A) Cleaning action of $\mathrm{OH}^{-}$

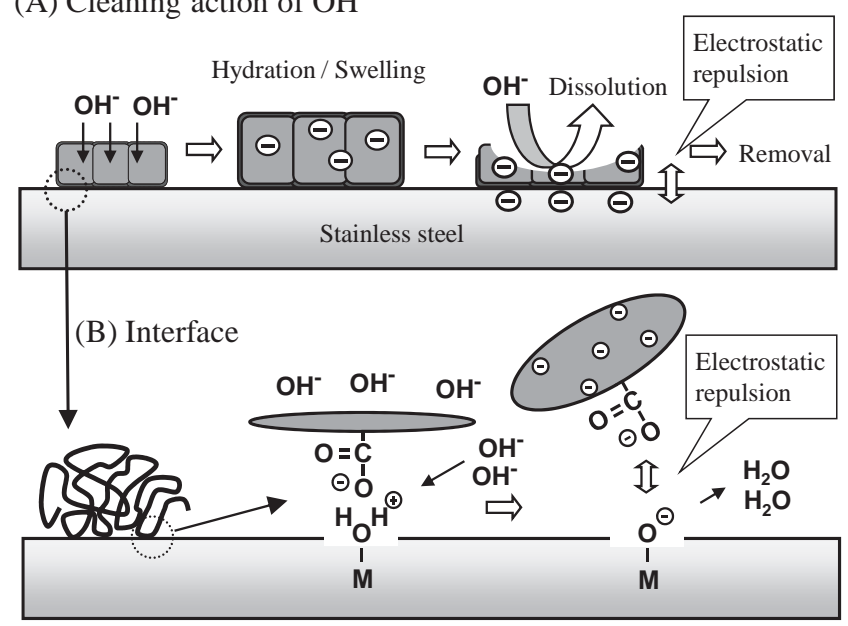

Fig. 6 Mechanism of the removal of protein from stainless steel surfaces by the action of $\mathrm{NaOH}-$.

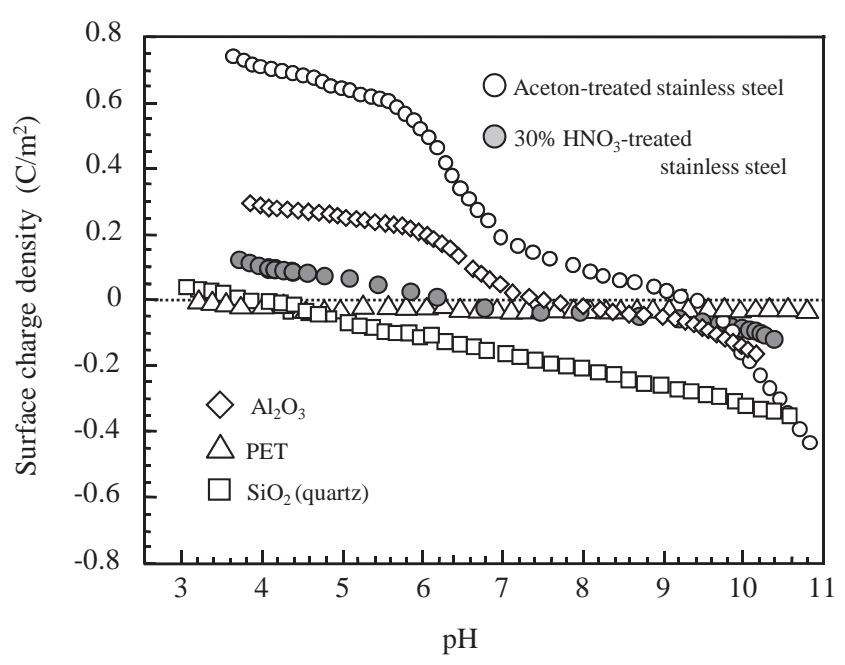

Fig. 7 Apparent surface charge densities of stainless steel (SUS 316L), silica, alumina, and PET particles as a function of $\mathrm{pH}$.

レス鋼 (アセトン洗浄)、10\% 硝酸処理 $316 \mathrm{~L}$ ステンレス鋼、 ポリエチレンテレフタレート（PET）を用いた研究例を紹 介する。

Fig. 7 に、各固体表面の見掛けの表面電荷密度曲線を示 す ${ }^{14)}$ 。酸化物 $\left(\mathrm{SiO}_{2}\right.$ と $\left.\mathrm{Al}_{2} \mathrm{O}_{3}\right)$ およびステンレス鋼は、い ずれも電気的に両性の性質を示しており、各々の零電荷点 $\left(\mathrm{pzc}_{\mathrm{app}}\right)$ は酸化物の種類や表面処理方法により大きく異な る。また、PETの場合は、分子鎖の一部に遊離のカルボキ シル基が存在するため、表面はわずかに負電荷を帯びてい るが、その絶対值は酸化物やステンレス鋼と比較すると 1 〜 2 桁低い值である。

Fig. 8 は、上記の硬質表面に対する pH5.0でのタンパク 質 (BSA) の飽和吸着量 $\left(\Gamma_{\text {sat }}\right)$ と、タンパク質が飽和吸
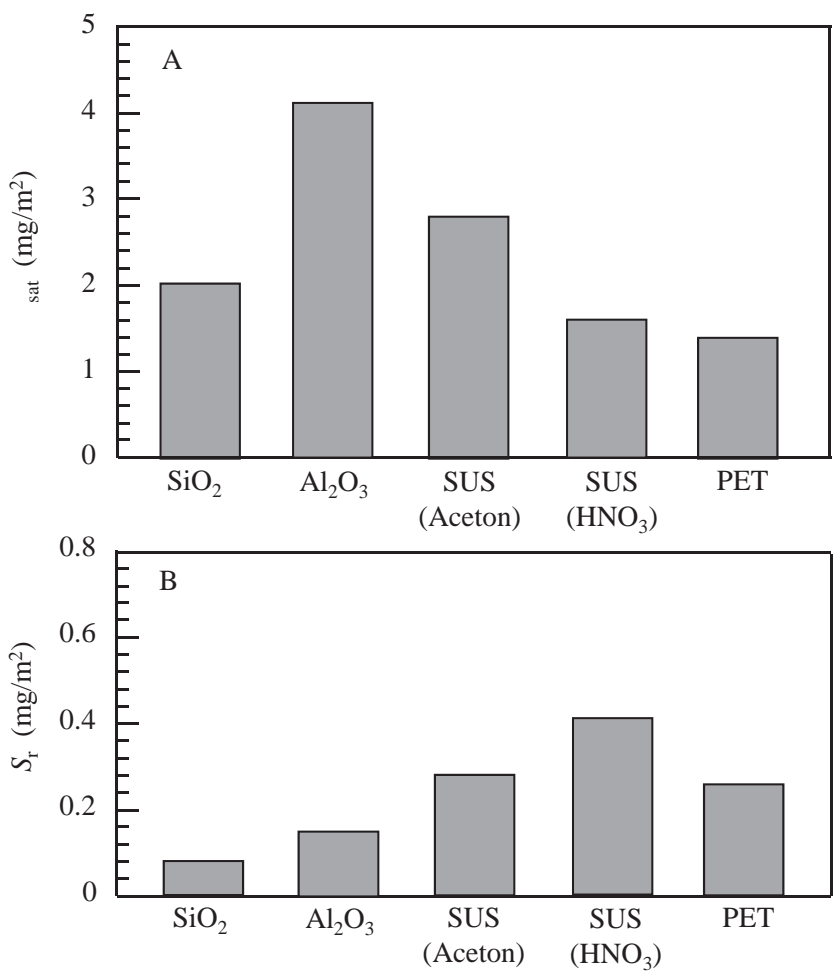

Fig. 8 Amounts of protein (BSA) adsorbed on various solid surfaces at $\mathrm{pH} 5$ and those remaining after cleaning with $0.1 \mathrm{M} \mathrm{NaOHsolutio.}$

着した各硬質表面を $0.1 \mathrm{M} \mathrm{NaOH}$ 溶液で回分洗浄処理した 後の残存量 $\left(S_{\mathrm{r}}\right)$ を比較した結果である ${ }^{14)}$ 。概括的に言え ば、吸着が起こった pH5.0における正の電荷密度が小さい ( $\mathrm{pzc}_{\mathrm{app}}$ の $\mathrm{pH}$ が酸性側に位置する) 表面において $\Gamma_{\text {sat }}$ が小 さく、アルカリ性条件下で負の電荷密度が大きい表面にお いて $S_{\mathrm{r}}$ が小さくなる（洗浄性が高い）傾向が見られる。例 えば、2つのステンレス鋼（アセトン洗浄、硝酸処理）を 比較すると、硝酸処理ステンレス鋼では「 $\Gamma_{\text {sat }}$ は小さいが、 $S_{\mathrm{r}}$ は大きい。PETの場合、「 $\mathrm{sat}$ はもっとも小さい值であるが、 $S_{\mathrm{r}}$ は比較的大きい。すなわち、 $\mathrm{SiO}_{2}$ (石英) のように正の 電荷密度が小さく、アルカリ性で負の電荷密度が大きくな る硬質表面が、BSA に対して抗付着性・易洗浄性を示す特 性といえる。これは、タンパク質が負電荷のカルボキシル 基を介して固体表面に吸着する傾向が強いことから、正電 荷表面に対する吸着相互作用が強くなるためである。一方、 負の電荷密度が小さい硬質表面は、 $\mathrm{OH}^{-}$の吸着サイト数が 少ないことになり、固液界面における静電的斥力と吸着置 換作用が十分に作用しないことが、低洗浄性の原因である。

\section{5. ステンレス鋼の熱履歴と洗浄性}

ステンレス鋼を高温で加熱処理すると酸化皮膜中での $\mathrm{Fe}$ の濃縮、不動態皮膜中の水和物の酸化（酸化物層の形成） ならびに表面水酸基の縮合脱水が起こる。その結果、表面 水酸基化度の低い $\mathrm{Fe}_{2} \mathrm{O}_{3}$ を主体とする酸化皮膜が形成され 


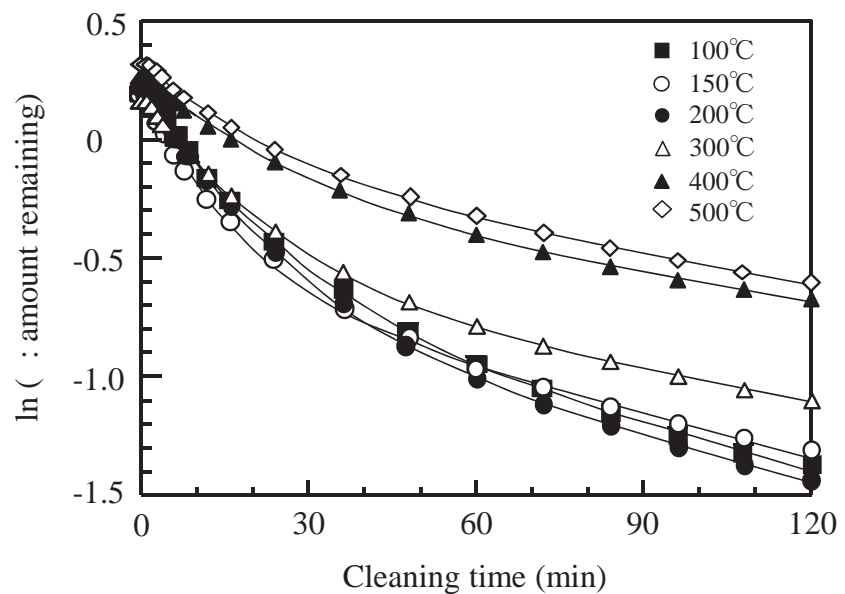

Fig. 9 Curves characterizing desorption of protein (BSA)from heattreated stainless steel (SUS 316L) at various temperatures during cleaning with $0.1 \mathrm{M} \mathrm{NaOHsolution}$

る ${ }^{15)}$ 。このようなステンレス鋼の表面変化は、タンパク質 に対する吸着親和性や洗浄性に変化をもたらす。さらに、 $700 \sim 850^{\circ} \mathrm{C}$ の鋭敏化温度域に一定時間保持されると、結晶 粒界部や最表面においてクロム炭化物の生成や構成元素の 偏析が起こる。実際、食品製造機器の配管の溶接継手部で は、洗浄操作後の污れの残留やバイオフィルムの形成がし ばしば観察されており、一般部材表面と比較して洗浄性に 劣ることが経験的に知られている ${ }^{1)}$ 2)。これは、溶接熱影 響部において鋭敏化あるいは構成元素の偏析が起こり、表 面化学組成の変化が起こった結果ではないかと推測されて いる。

\section{1 加熱ステンレス鋼と洗浄性}

Fig. 9 に、種々の温度で 4 時間加熱したステンレス鋼 （SUS 316L）にタンパク質（BSA）を吸着させた後、0.1M 水酸化ナトリウム溶液で洗浄したときの洗浄曲線を示す 15)。300 $\mathrm{C}$ 以上で加熱処理したステンレス鋼では、温度に依 存してタンパク質の離脱速度は緩慢となり、120 分後の残 存量も多い結果となる。(3) 式を用いた解析の結果、加熱温 度が $100^{\circ} \mathrm{C}$ から $500^{\circ} \mathrm{C}$ に増加すると、 $k^{\mathrm{f}}$ は $0.057 \mathrm{~min}^{-1}\left(100^{\circ} \mathrm{C}\right)$ から $0.047 \mathrm{~min}^{-1}\left(500^{\circ} \mathrm{C}\right) \sim 1.2$ 倍減少し、 $k^{\mathrm{s}}$ は $0.0062 \mathrm{~min}^{-1}$ $\left(100^{\circ} \mathrm{C}\right)$ から $0.041 \mathrm{~min}^{-1}\left(500^{\circ} \mathrm{C}\right) \sim 1.5$ 倍減少すると概算 される。洗浄性の低下は、ステンレス鋼表面の Fe の濃縮お よびアルカリ性領域での負電荷密度の減少と相関する変化 であることが示されているが ${ }^{15)}$ 、詳細は明らかになってい ない。

\section{2 溶体化処理による洗浄性の改善}

低炭素ステンレス鋼である SUS 316L（粒子）を用いて、 疑似的に鋭敏化処理 $\left(700^{\circ} \mathrm{C}\right.$ で 100 時間保持後に除冷）を 行うと、ステンレス鋼の表面に $\mathrm{Cr}$ 析出物の生成や $\mathrm{Mn}$ の偏 析が起こる。ここでは、洗浄性に及ぼす疑似鋭敏化（偏析）

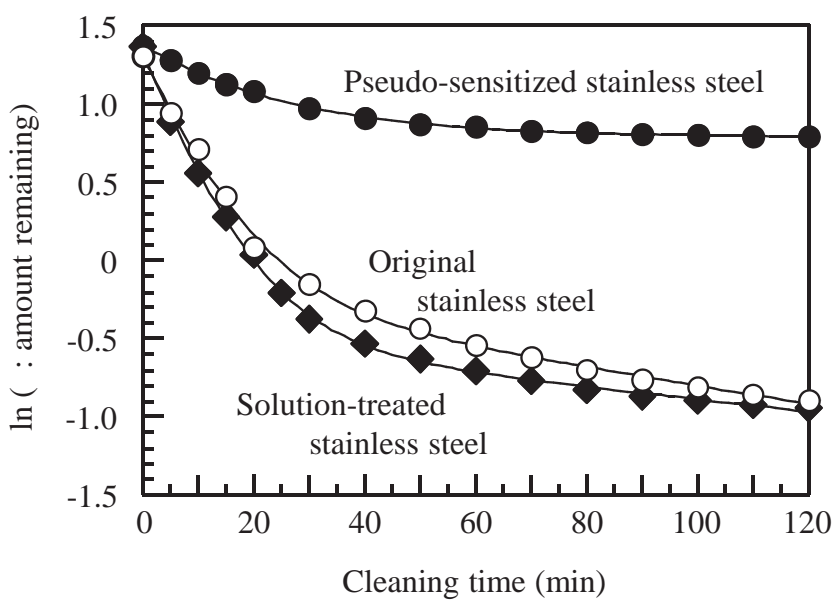

Fig. 10 Curves characterizing desorption of protein (BSA)from original, pseudo-sensitized, and solution-treated stainless steel (SUS $316 \mathrm{~L}$ ) during cleaning with $0.1 \mathrm{M} \mathrm{NaOHsolution.}$

の影響と、溶体化処理 $\left(1,050^{\circ} \mathrm{C} て ゙ 1\right.$ 時間保持後に急冷 $)$ に よる回復効果について紹介する。

Fig. 10 に、疑似鋭敏化処理および溶体化処理ステンレス 鋼にタンパク質（BSA）を一定量吸着させた後、0.1M 水酸 化ナトリウム溶液で洗浄したときのBSA の離脱曲線を示す 16)。鋭敏化処理材では、タンパク質の離脱はきわめて緩慢 であり、洗浄中期以降では離脱はほとんど起こっておらず、 洗浄性は著しく低下していることがわかる。一方、この疑 似鋭敏化処理ステンレス鋼を溶体化処理すると、表面の $\mathrm{Cr}$ 析出物ならびに $\mathrm{MnO}$ が粒内に固溶し、表面の化学組成な らびに表面電荷特性を元の未処理材の状態に戻すことがで きる (結果未掲載)。その結果、離脱速度および洗浄終了時 (120 分) の残存量は、未処理材とほぼ同等なレベルまで改 善することができている。(3) 式を用いた解析の結果、鋭敏 化処理材に対して得られた $k^{\mathrm{f}} と k^{\mathrm{s}}\left(0.046 \mathrm{~min}^{-1}, 0.00018 \mathrm{~min}^{-1}\right)$ は、未処理材 $\left(0.092 \mathrm{~min}^{-1}, 0.0059 \mathrm{~min}^{-1}\right)$ と比較すると、各々 2 倍および 33 倍も小さいと算出される。また、溶体化処理 材に対して得られた $k^{\mathrm{f}} と k^{\mathrm{s}}\left(0.099 \mathrm{~min}^{-1}, 0.0039 \mathrm{~min}^{-1}\right)$ は、 未処理材とほぼ同等の数值となる。

\section{6. おわりに}

ここでは、アルカリ剤 $\left(\mathrm{OH}^{-}\right)$によるステンレス鋼表面 からのタンパク質の除去特性を中心に概説した。従来、ス テンレス鋼の污染性や洗浄性については、耐食性や加工性 を基準に鋼種や表面仕上げ (平滑性) の影響が検討されて きたが、不動態皮膜の化学組成および表面電荷特性という 観点から解析した研究例は少ない。洗浄操作により、タン パク質などの付着層を除去することは、バイオフィルムの 形成を防止するための基本的な対策である。効率的かつ有 効な洗浄を実施するためには、種々の環境因子により、ス テンレス鋼の界面化学的特性が変化し、洗浄性までもが変 
化することを認識しておくことが重要である。

\section{引用文献}

1) European Hygienic Equipment Design Group: Trends Food Sci. Technol., 4 (1993) 306-310.

2) European Hygienic Equipment Design Group: Trends Food Sci. Technol., 4 (1993) 375-379.

3) 福崎智司：まてりあ、43 (2004) 418-424.

4) S. Fukuzaki, A. Takehara, K. Takahashi, M. Hiramatsu, and K. Koike: J. Surface Finish. Soc. Jpn., 54 (2003) 1034-1042.

5) 福崎智司：ふえらむ、12 (2007) 578-584.

6) K. Nakanishi, T. Sakiyama, and K. Imamura: J. Biosci. Bioeng., 91 (2001) 233-244.

7) S. Fukuzaki, H. Urano, and M. Hiramatsu: J. Surface Finish. Soc. Jpn., 49 (1998) 915-916.
8) T. Sakiyama, K. Tanino, M. Urakawa, K. Imamura, T. Takahashi, T. Nagai, and K. Nakanishi: J. Biosci. Bioeng., 88 (1999) 536-541.

9) H. Urano and S. Fukuzaki: J. Biosci. Bioeng., 90 (2000) 105-111.

10) H. Urano and S. Fukuzaki: J. Colloid Interface Sci., 252 (2002) 284289.

11) 福崎智司、浦野博水 : New Food Ind., 51 (2004) 92-97.

12) 福崎智司：冷凍、77 (2002) 759-764.

13）福崎智司：“フレッシュ食品の高品質殺菌技術”、サイエンス フォーラム (2008) 167-178.

14) 福崎智司: 平成 18 年度都市エリア産官学連携推進事業共同研 究報告書、(2007) 55-67.

15) K. Takahashi and S. Fukuzaki: Biocontrol Sci., 11 (2006) 61-68.

16) S. Fukuzaki, K. Takahashi, and A. Takagi: Biocontrol Sci., 13 (2008) 57-63. 